\title{
Breast Cancer Clinical Distant Metastasis TNM Finding v7
}

National Cancer Institute

\section{Source}

National Cancer Institute. Breast Cancer Clinical Distant Metastasis TNM Finding v7. NCI

Thesaurus. Code C88371.

A clinical finding about one or more characteristics of breast cancer, following the rules of the TNM AJCC V7 classification system as they pertain to distant metastases. 